\title{
Evaluation of healthcare policy in Latvia
}

\author{
I. Bikava and A. Skride \\ Rīga Stradinš̌ University, Riga, Latvia
}

\begin{abstract}
Performance of healthcare system of Latvia has been criticised for several years, due to the problems of accessibility, weak efficiency and insufficient funding. Politicians, foreign and local experts all agree upon the need of reforms to improve the performance of the healthcare system. The aims are defined in long-term policy documents, but there are no defined tasks to be made and aims to be achieved in mid-term and shortterm policy.

The aim of the research was to make evaluation of performance of Latvia healthcare system as well as evaluation according to "Health 2020" framework recommendations.

The results showed that changes in the healthcare system in Latvia are made on "ad-hoc" basis without a strategic long-term plan, and despite the fact that guidelines on the public health refer to "Health 2020", the changes that are made and reforms that are planned are not in compliance with "Health 2020". Work on social determinants (equity, universal coverage, accessibility) hasn't been effective, the aim "health in all policies" hasn't been achieved and the primary healthcare due to its unaccessibility doesn't provide expected efficiency in the whole healthcare system.

Key words: Healthcare policy; healthcare reforms; healthcare governance.
\end{abstract}

\section{Introduction}

Researchers, politicians, local and foreign experts all agree upon the need of healthcare reforms in Latvia to improve inhabitants' access to healthcare and provide sustainability of healthcare resources.

In the case of Latvia important factors are - urban and rural regional differences, high degree of income disparities and high proportion of the people who are at the risk of poverty.

Since 1991, when Latvia regained its independence, different reforms in Latvia healthcare system have been made. First reforms began in 1993 with Healthcare financing reform, effective healthcare provider network development and public health policy development. In 1996 the reform to implement primary and secondary healthcare providers began. To improve health of the society, primary healthcare based on General Practitioners (GP) was promoted to provide available and cost effective healthcare services to patients as close to the patients' homes as possible. The reforms in secondary healthcare were made to optimize network of service providers and to improve the quality, cost efficiency and availability to patients. Financing model change was made in 1997 by implementing health insurance principles in the healthcare. The public health policy development started in 2001 by developing the "Public Health Strategy". The second change on financing model took 
place in 2004 by refusing of the insurance principle and with return to healthcare financing from the state budget $[1,2]$.

During 1997-2015 the number of hospitals has decreased from 156 to 67 , the number of healthcare institutions providing outpatient services has increased from 1127 to 4192, the number of general medical practices (GP, pediatricians, internists) has increased from 361 to 1275 , the number of other outpatient healthcare institutions has increased from 75 to 729 [3].

The reforms have impact not only on the number of institutions, but also on medical personnel. During 1997-2015 the total number of physicians per 10000 inhabitants has increased from 34.7 to 38.7 , but the number of nurses has significantly decreased from 46.2 to 38.7 with the lowest number of nurses in $2009-37.6$ [4, 5]. The decrease in numbers can be explained by two main reasons - low income that leads to the situation that nurses are working in another, a better paid field, and secondly - open borders of the European Union that lead to the situation that a significant amount of the medical personnel chooses to live and work in another European country. In accordance with the European Commission report: "The number of practising doctors per capita is just below the EU average. However, the number of practising nurses per capita is among the lowest in EU. The age of doctors and nurses is rapidly increasing threatening the sustainability of providing healthcare services." [6]

There have been reforms implemented and a lot of changes made in institutional network, normative regulations and treatment guidelines with the general aim to provide service availability to patients and to make the system more effective and efficient. Each Minister of Health had made changes in regulations and short-term planning documents, had nominated priorities for the period and done some work to achieve their nominated goals. However, in accordance with the opinion of the society - the situation is not satisfactory.

One of the indicators reflecting the level of service availability is the range of unmet needs that are measured in Latvia since 2005. During 2005-2014 the range of unmet needs has decreased from $29.4 \%$ to $19.2 \%$, however the proportion of unmet needs is still significantly high. In the first quintile group (a group of people where household income is at its lowest), the rate of unmet needs has been significantly high during the whole period $34.5 \%$ to $28.4 \%$, with the highest rate of $35.3 \%$ in 2006 . The main reason for unmet needs during the whole period was "could not afford to (too expensive)". The range in the whole population was $55.5 \%$ in 2005 , it reached its the lowest point of $34.9 \%$ in 2007 and increased again after economic crises reaching the highest point of $65.5 \%$ in 2011 [7].

The Ministry of Health in 2016 was still working on the nominated priorities and implementation of different reforms that should provide better access, efficiency and effectiveness in healthcare.

The reforms that are planned to be made in healthcare system should be coherent to the society needs and in accordance with healthcare long-term policy.

Long-term policy document in Latvia is "Sustainable Development Strategy of Latvia until 2030". The main priorities in healthcare according to the document are investments in human capital - quality and availability of health and social services. Investments in human capital have to be made to ensure the participation of all potential human resources, particularly the groups of inhabitants subjected to the risk of poverty and social exclusion in the labour market [8].

Mid-term policy document for healthcare in Latvia is "Public Health Guidelines 20142020". As written in the document, guidelines are a mid-term policy planning document, which is based on the World Health Organization (WHO) Regional Strategy for Europe "Health 2020". The document "Public Health Guidelines" identifies main problems in Latvia healthcare system: insufficient financial support from the state and high level of 
direct payments that has significant impact on the access to healthcare. Therefore healthcare system solves neglected health problems as patients do not always have the possibility to find a doctor in a due time. The supreme goal of the policy is to increase the number of healthy life years of the inhabitants and to prevent premature death by preserving, improving and restoring health [9].

The aim of the research was to evaluate health policy in Latvia according to the society needs and changes in the healthcare system performance during 2008-2015 and to analyze developed reforms in accordance with the health policy framework "Health 2020" on which health policy guidelines of Latvia for 2014-2020 are based.

WHO policy framework "Health 2020" focuses on improvement of the citizens' health and reduction of health inequalities through better leadership and governance for health. "Health 2020" suggests shifting mindset from combating illness to promotion of health and well-being. "Health 2020" policy framework is based on values: universality, solidarity and equal access and includes - fairness, sustainability, quality, transparency, accountability, gender equality, dignity and the right to participate in decision making [10].

The aim of the research was to evaluate the healthcare system performance in Latvia and analyze the outcome of reforms made in the recent years as well as to evaluate the reforms in accordance to the recommendations given in the health policy framework "Health 2020".

\section{Healthcare system performance in Latvia 2008-2015}

Information about the healthcare system performance is essential to evaluate healthcare policy because it provides ability to measure the outcome and compare it in a selected time period or in comparison to other countries. An overall system performance measurement within a time period can be an indicator of the policy outcome - to determine how implemented reforms influence the performance.

Evaluation of the healthcare system performance in Latvia is made based on Irene Papinicolas and Peter C. Smith described performance assessment framework used to compare healthcare systems in different countries. In accordance with the noted in introduction, their work summarizes the current "state of the art" of health system comparison and is based on the performance comparison indicators used by the European Commission, Organisation for Economic Co-operation and Development, the Commonwealth Fund and the WHO. The framework includes analysis of five key elements of the health system architecture - service provision, financing, resource generation, leadership/governance and risk factors. To evaluate the healthcare policy outcome and performance of healthcare system, five segments have to be evaluated - population health, health service outcome, equity, fairness in financing and responsiveness [11].

Identified problems in evaluation process of each segment are analyzed in accordance with the recommendations in "Health 2020".

\subsection{Health of the population}

Population's health is the domain, which can be evaluated basing on the commonly available data - life expectancy, mortality and morbidity.

Life expectancy at birth in Latvia, as can be seen in Table 1, during the period 20082015 has increased in total from 72.0 to 74.7 years. Life expectancy for males has increased by 3.2 years and for females -1.9 years. 
Table 1. Life expectancy at birth (years).

\begin{tabular}{|l|c|c|c|c|c|c|c|c|}
\hline Year & $\mathbf{2 0 0 8}$ & $\mathbf{2 0 0 9}$ & $\mathbf{2 0 1 0}$ & $\mathbf{2 0 1 1}$ & $\mathbf{2 0 1 2}$ & $\mathbf{2 0 1 3}$ & $\mathbf{2 0 1 4}$ & $\mathbf{2 0 1 5}$ \\
\hline Total & 72.0 & 72.7 & 73.1 & 73.7 & 74.0 & 74.2 & 74.3 & 74.7 \\
\hline Males & 66.5 & 67.5 & 67.9 & 68.6 & 68.9 & 69.3 & 69.1 & 69.7 \\
\hline Females & 77.4 & 77.6 & 77.9 & 78.5 & 78.7 & 78.7 & 79.3 & 79.3 \\
\hline
\end{tabular}

Data source: Central Statistical Bureau of Latvia [13].

Rate of infant death to 1000 live birth, as can be seen in Table 2, has decreased from 6.6 to 4.1. Perinatal mortality which is more sensitive to the quality of medical care has decreased from 9.0 to 6.7 and neonatal mortality rate has also decreased significantly from 4.6 to 2.4 .

Table 2. Perinatal, neonatal and infant death rates.

\begin{tabular}{|l|c|c|c|c|c|c|c|c|}
\hline Year & $\mathbf{2 0 0 8}$ & $\mathbf{2 0 0 9}$ & $\mathbf{2 0 1 0}$ & $\mathbf{2 0 1 1}$ & $\mathbf{2 0 1 2}$ & $\mathbf{2 0 1 3}$ & $\mathbf{2 0 1 4}$ & $\mathbf{2 0 1 5}$ \\
\hline $\begin{array}{l}\text { Infant deaths (from 0 } \\
\text { days to 1 year) }\end{array}$ & 6.6 & 7.6 & 5.6 & 6.6 & 6.3 & 4.4 & 3.8 & 4.1 \\
\hline $\begin{array}{l}\text { Perinatal mortality } \\
\text { (stillbirths and 0-6 days } \\
\text { old) }\end{array}$ & 9.0 & 9.3 & 7.9 & 9.1 & 8.5 & 7.3 & 7.2 & 6.7 \\
\hline $\begin{array}{l}\text { Neonatal mortility (0-27 } \\
\text { days old) }\end{array}$ & 4.6 & 4.9 & 3.4 & 4.3 & 4.2 & 2.5 & 2.8 & 2.4 \\
\hline
\end{tabular}

Data source: Central Statistical Bureau of Latvia [14].

In accordance with these indicators, overall environment and medical care provide possibilities to live longer, but do not represent the quality of the healthcare system. Mortality by cause provides clearer image on the public health.

The leading cause of death, as can be seen in Table 3, is diseases of the circulatory system and the death rate in this group of diseases has increased from 750.7 in 2009 to 806.10 in 2014 . The leading cause of circulatory system diseases is Ischemic heart diseases (IHD) and the death rate from IHD has increased from 401.2 to 405.6.

Table 3. Leading causes of death by cause group (100 000 inhabitants).

\begin{tabular}{|l|c|c|c|c|c|c|}
\hline Death rates by cause/year & $\mathbf{2 0 0 9}$ & $\mathbf{2 0 1 0}$ & $\mathbf{2 0 1 1}$ & $\mathbf{2 0 1 2}$ & $\mathbf{2 0 1 3}$ & $\mathbf{2 0 1 4}$ \\
\hline $\begin{array}{l}\text { I00-I99 Diseases of the } \\
\text { circulatory system }\end{array}$ & 750.7 & 776.1 & 760.9 & 801.9 & 812.8 & 806.1 \\
\hline $\begin{array}{l}\text { I20-I25 Ischemic heart } \\
\text { diseases }\end{array}$ & 401.2 & 409.6 & 406.2 & 418.6 & 412.0 & 405.6 \\
\hline C00-D48 Neoplasms & 281.5 & 292.1 & 289.6 & 299.7 & 300.4 & 304.9 \\
\hline $\begin{array}{l}\text { V01-Y89 External causes of } \\
\text { morbidity and mortality }\end{array}$ & 100.8 & 100.5 & 89.3 & 92.9 & 89.6 & 93.8 \\
\hline $\begin{array}{l}\text { F01-F99 Mental and } \\
\text { behavioural disorders }\end{array}$ & 11.2 & 12.2 & 15.5 & 14.8 & 16.9 & 15.3 \\
\hline
\end{tabular}

Data source: Centre for Disease Prevention and Control of Latvia [15].

The second leading cause of death is neoplasms where the rate has increased from 281.5 to 300.4. Next leading cause group are external causes that have decreased from 100.8 to 
93.8. Leading causes of mortality are common to the whole situation in region, where the leading cause is circulatory diseases.

The data indicates that the situation has not improved, because the leading group of diseases is IHD, which is an indicator of premature mortality in industrialized countries and it has increased. IHD are attributed to prevalence of risk factors such as smoking, high cholesterol and hypertension. Persisting high level of mortality from IHD usually indicates systematic problems that cover the entire course of the disease - from primary prevention and health promotion to treatment [11].

There are also some specific groups of diseases that can be analyzed to evaluate performance of healthcare system - diabetes treatment, mental and behaviour disorders and neoplasms on which there are screening programmes run by the state.

Death rate from diabetes, as can be seen in Table 4, has increased from 23.7 in 2009 to 25.3 in 2014 . The rate of mortality from mental and behavioural diseases has also increased from 11.2 to 15.3 and in 2013 has reached the rate of 16.9. The increase indicates that availability of the primary care is not sufficient.

Table 4. Death rates by cause group (100 000 inhabitants).

\begin{tabular}{|l|c|c|c|c|c|c|}
\hline Death rates by cause/year & $\mathbf{2 0 0 9}$ & $\mathbf{2 0 1 0}$ & $\mathbf{2 0 1 1}$ & $\mathbf{2 0 1 2}$ & $\mathbf{2 0 1 3}$ & $\mathbf{2 0 1 4}$ \\
\hline $\begin{array}{l}\text { C61 Malignant neoplasm of } \\
\text { prostate }\end{array}$ & 35.6 & 37.8 & 39.5 & 42.3 & 39.9 & 44.74 \\
\hline E10-E14 Diabetes mellitus & 23.7 & 25.6 & 23.6 & 23.1 & 22.8 & 25.3 \\
\hline $\begin{array}{l}\text { C50 Malignant neoplasm of } \\
\text { breast }\end{array}$ & 20.7 & 20.3 & 21.7 & 19.9 & 21.7 & 22.2 \\
\hline $\begin{array}{l}\text { C54 Malignant neoplasm of } \\
\text { corpus uteri }\end{array}$ & 11.1 & 10.5 & 11 & 13.2 & 10.8 & 9.7 \\
\hline
\end{tabular}

Data source: Centre for Disease Prevention and Control of Latvia [15].

There are three screening programmes for neoplasms provided by the state in Latvia for females: breast cancer and cervical cancer and for males - prostate cancer. Despite the programmes, mortality rate from these diseases is high: mortality from breast cancer, as can be seen in Table 4, has increased from 20.7 to 22.2, for prostate cancer from 35.6 to 44.74 and only from cervical cancer mortality has decreased from 11.1 to 9.7. In accordance with the indicators the screening campaigns and the state run programmes have not performed successfully.

Unfortunately, indicators that are widely used to evaluate the health of the population years of life lost, disability adjusted life years (DALYs), avoidable morbidity, amenable mortality and preventable mortality - are not available for the selected period in Latvia. However, in accordance with the data available on the population mortality - healthcare system is not performing successfully.

To improve the public health the recommendation given in "Health 2020 " is to create social and physical environment that fosters healthy behaviour: tobacco control programmes (raising tax, encourage smoke-free environment, banning advertisements, etc) changes in alcohol policies (raising tax, restricting access, enforcing bans on advertising, restricting drink-driving), prevent road crashes (one-way streets, mandatory speed limits, radar speed enforcement programmes) [9].

According to normative regulations on tobacco and alcohol, as well as on traffic safety proposed changes recommended by WHO had already been implemented in the legislature in Latvia. Those amendments had positive impact on the death rate decrease from external causes from 100.8 to 93.8 . 
Another group of recommendations given by WHO are actions to promote healthy eating - reformulating processed food, decreasing salt, trans-fatty acids and saturated fat and promoting healthier food - more fruit and vegetables for children. As well as promoting physical activity through social media campaign and also initiating changes in the transport system and urban design [9].

There have been campaigns to promote healthier eating and physical activities, especially for school-age children, also changes in legislature have been made, providing restrictions on beverages that could be sold in schools. Also changes in urban designs can be observed - especially the popularity of bicycle roads in the city. However, death rate from IHD has increased as well as obesity and overweight rate in children and youth which indicates that the situation is not satisfactory and more changes have to be made to impact a healthy lifestyle and behaviour factors in the inhabitants [12].

\subsection{Healthcare service outcomes}

Healthcare service outcomes has to be analyzed using information about the performance of different areas of healthcare services - standardized hospital mortality rates, case fatality rates for acute myocardial infarction (AMI) and stroke, the postponement of death, readmission rates, patient safety indicators, administrative convenience [11]. Unfortunately, there is no data publicly available on these indicators in Latvia.

Another healthcare evaluation aspect is measuring the contribution of primary healthcare to healthcare system performance, because primary healthcare system is an essential element for an efficient and effective health system and cornerstone on health systems in the 21 st century $[9,11]$.

To evaluate proper resource usage, medical rescue service calls have been compared the number of acute cases to the number of inappropriate cases when a patient could get the needed medical help in the primary healthcare.

Table 5. Emergency medical rescue service usage.

\begin{tabular}{|c|c|c|c|c|c|c|c|c|}
\hline $\begin{array}{l}\text { EMR } \\
\text { episode/year }\end{array}$ & 2008 & 2009 & 2010 & 2011 & 2012 & 2013 & 2014 & 2015 \\
\hline $\begin{array}{l}\text { Total EMR } \\
\text { episodes }\end{array}$ & $\begin{array}{l}427 \\
881\end{array}$ & $\begin{array}{l}371 \\
209\end{array}$ & $\begin{array}{l}432 \\
360\end{array}$ & $\begin{array}{l}461 \\
258\end{array}$ & $\begin{array}{l}460 \\
229\end{array}$ & $\begin{array}{l}451 \\
972\end{array}$ & $\begin{array}{l}436 \\
245\end{array}$ & $\begin{array}{l}443 \\
215\end{array}$ \\
\hline $\begin{array}{l}\text { Episodes } \\
\text { without results }\end{array}$ & 31531 & 25479 & 31563 & 37114 & 27881 & 28855 & 30713 & 30834 \\
\hline $\begin{array}{l}\text { Episodes } \\
\text { without results }\end{array}$ & $7.3 \%$ & $6.9 \%$ & $7.3 \%$ & $8.0 \%$ & $6.1 \%$ & $6.4 \%$ & $7.0 \%$ & $7.0 \%$ \\
\hline Critical cases & $\begin{array}{l}301 \\
960 \\
\end{array}$ & $\begin{array}{l}260 \\
765 \\
\end{array}$ & $\begin{array}{l}279 \\
752 \\
\end{array}$ & $\begin{array}{l}281 \\
804 \\
\end{array}$ & $\begin{array}{l}293 \\
286 \\
\end{array}$ & $\begin{array}{l}286 \\
676 \\
\end{array}$ & $\begin{array}{l}259 \\
864 \\
\end{array}$ & $\begin{array}{l}243 \\
356 \\
\end{array}$ \\
\hline Critical cases & $70.6 \%$ & $70.2 \%$ & $64.7 \%$ & $61.1 \%$ & $63.7 \%$ & $63.4 \%$ & $59.6 \%$ & $54.9 \%$ \\
\hline $\begin{array}{l}\text { Non critical } \\
\text { cases }\end{array}$ & 94410 & 84986 & $\begin{array}{l}121 \\
072\end{array}$ & $\begin{array}{l}142 \\
370\end{array}$ & $\begin{array}{l}139 \\
091\end{array}$ & $\begin{array}{l}136 \\
470\end{array}$ & $\begin{array}{l}145 \\
700\end{array}$ & $\begin{array}{l}169 \\
062\end{array}$ \\
\hline $\begin{array}{l}\text { Non critical } \\
\text { cases }\end{array}$ & $22.1 \%$ & $22.9 \%$ & $28.0 \%$ & $30.9 \%$ & $30.2 \%$ & $30.2 \%$ & $33.4 \%$ & $38.1 \%$ \\
\hline $\begin{array}{l}\mathrm{CC}-\text { injuries, } \\
\text { accidents }\end{array}$ & $15 \%$ & $14 \%$ & $14 \%$ & $14 \%$ & $15 \%$ & $15 \%$ & $16 \%$ & $15 \%$ \\
\hline $\begin{array}{l}\text { CC - sudden } \\
\text { morbidity, } \\
\text { acute cases }\end{array}$ & $46 \%$ & $47 \%$ & $43 \%$ & $40 \%$ & $42 \%$ & $42 \%$ & $37 \%$ & $34 \%$ \\
\hline $\begin{array}{l}\text { CC- } \\
\text { childbirth and } \\
\text { pregnancy } \\
\text { pathologies }\end{array}$ & $1.2 \%$ & $1.3 \%$ & $1.1 \%$ & $0.9 \%$ & $0.9 \%$ & $1.7 \%$ & $1.9 \%$ & $1.7 \%$ \\
\hline $\begin{array}{l}\mathrm{CC}- \\
\text { transportation }\end{array}$ & $8 \%$ & $8 \%$ & $6 \%$ & $6 \%$ & $6 \%$ & $5 \%$ & $5 \%$ & $5 \%$ \\
\hline
\end{tabular}




\begin{tabular}{|l|c|c|c|c|c|c|c|c|}
$\begin{array}{l}\text { NCC - } \\
\text { morbidity }\end{array}$ & $20 \%$ & $21 \%$ & $27 \%$ & $30 \%$ & $29 \%$ & $29 \%$ & $32 \%$ & $37 \%$ \\
\hline $\begin{array}{l}\text { NCC - } \\
\text { transportation }\end{array}$ & $3 \%$ & $2 \%$ & $1 \%$ & $1 \%$ & $1 \%$ & $1 \%$ & $1 \%$ & $2 \%$ \\
\hline
\end{tabular}

Data source: Centre for Disease Prevention and Control of Latvia [16].

In accordance with the data from the use of emergency medical help episodes, as can be seen in Table 5, the number of acute cases has decreased from $71 \%$ to $55 \%$ of the total count of episodes, the number of cases associated with injuries and accidents is stable about $15 \%$, but the number of sudden morbidity and acute cases has decreased. However, the number of non-critical cases, when emergency service is used, has significantly increased from $22 \%$ to $38 \%$ as well as non-acute morbidity cases have risen from $20 \%$ to $37 \%$.

The data shows that resources are not used efficiently and the performance of primary care is not sufficient. The main problem, as announced by the Head of the RAKUS (the largest hospital in Latvia), is that daily the Emergency department receives in average 314 patients out of which 200 are not hospitalised. In the Emergency department those patients get blood tests, cardiograms, computer tomography and other diagnostic services, receive consultations and treatment recommendations [17].

Allocated efficiently, expressed by share of GDP, is the government spending on the healthcare sector relative to other sectors can be another indicator of the resource use [11]. In Latvia the public resource allocation is unsatisfactory, because the state expenditure on health is about $3 \%$ of GDP or about $10 \%$ of the state budgetary expenditure, that is relatively low compared to other EU countries.

As mentioned in "Health 2020", the concept "Health in all policies" is designed to make governance for health and well-being a priority for more than just the health sector. It has to work in both directions - ensuring that all sectors understand and act on their responsibility for health while recognizing how health affects other sectors [9].

As can be observed in the case of Latvia, there is no doubt that healthcare system is insufficiently financed and that healthcare sector has problems. But there are no activities taken - healthcare is no priority in the government. Despite all expert advice, the expenditure on healthcare from the state is only about $10 \%$ instead of at least $14 \%$ and the healthcare as priority is declared only for the year 2018. But for now, Latvia is a country with the second lowest expenditure on healthcare among developed countries per OECD data [18].

As outlined in "Health 2020", in the conditions of restricted state funding, effective resource usage is one of the main subjects that Ministry of Health and authorities have to work on. Targeting public expenditures according to the social need protects the poor and vulnerable people. The recommended directions to work in are - health technology assessment that can provide cost effective use of medicine and seeking efficiency gains by rationalizing the service delivery structures [9].

As previously mentioned, there are problems with availability for services in primary healthcare for the poor and vulnerable people, but there are no reforms planned in the near future that could provide better accessibility to primary healthcare. The current Minister of Health is working on the priorities called "green passageway for oncology patients" and "the health of mother and child", but not to improve accessibility to GP as the cornerstone of effective and efficient healthcare system.

Health technology assessment, as recommended by WHO, to provide cost effective healthcare, is not used since 2009 when the Centre of Health Economy of Latvia has been shut down and merged into the National Health Service. 
Work on the development of effective service providers has started, following the report of The World Bank, but there are doubts about the outcome of the reform, because of the political setting that no hospital should be closed.

\subsection{Equity}

Evaluation on the third domain "equity" is made based on the distribution of health, progressivity of financing system and distribution responsiveness of health services: equity in health status, including socio-economic, demographic factors and genetics [9].

In the case of Latvia equity is declared as a normative value, but there is no equal access to healthcare for all inhabitants. In accordance with socio-economic situation, there is a high proportion of people that are at poverty and social exclusion risk as mentioned before.

The proportion of this group of people, as can be seen in Table 6, is high in the whole society with variance from $30 \%$ to $40 \%$ of the total population. The highest proportion of people at poverty and social exclusion risk is in the age group 55 and older, i.e., the group that has the highest need of healthcare.

Analysis of unmet needs in the age group 55 and older indicated that in the households with the lowest income the main reason for unmet needs is "cannot afford to (too expensive)" [7].

Table 6. People at risk of poverty or social exclusion.

\begin{tabular}{|l|c|c|c|c|c|c|c|c|}
\hline Year & $\mathbf{2 0 0 8}$ & $\mathbf{2 0 0 9}$ & $\mathbf{2 0 1 0}$ & $\mathbf{2 0 1 1}$ & $\mathbf{2 0 1 2}$ & $\mathbf{2 0 1 3}$ & $\mathbf{2 0 1 4}$ & $\mathbf{2 0 1 5}$ \\
\hline Total & $34.2 \%$ & $37.9 \%$ & $38.2 \%$ & $40.1 \%$ & $36.2 \%$ & $35.1 \%$ & $32.7 \%$ & $30.9 \%$ \\
\hline Age: under $\mathbf{1 6}$ & $31.5 \%$ & $37.8 \%$ & $42.0 \%$ & $43.7 \%$ & $39.1 \%$ & $37.0 \%$ & $34.5 \%$ & $30.3 \%$ \\
\hline Age: $\mathbf{1 6}-\mathbf{2 4}$ & $27.7 \%$ & $33.8 \%$ & $39.7 \%$ & $44.2 \%$ & $39.1 \%$ & $38.7 \%$ & $32.7 \%$ & $33.5 \%$ \\
\hline Age: $\mathbf{2 5 - 5 4}$ & $26.3 \%$ & $31.2 \%$ & $36.2 \%$ & $39.7 \%$ & $35.0 \%$ & $32.9 \%$ & $28.6 \%$ & $25.1 \%$ \\
\hline Age: $\mathbf{5 5}+$ & $50.4 \%$ & $49.4 \%$ & $38.3 \%$ & $37.2 \%$ & $35.4 \%$ & $36.0 \%$ & $37.1 \%$ & $37.7 \%$ \\
\hline
\end{tabular}

Data source: Eurostat [19].

\subsection{Fairness of financing}

The fourth domain that has to be evaluated is "fairness of financing". In case of Latvia, the share of out-of-pocket payments is very high and varies from $32.1 \%$ to $36.1 \%$ of the total expenditure on health.[20] That indicates that the financing system is more regressive than progressive.

Because of insufficient funding of healthcare from the state there are several groups of people for whom healthcare is not accessible due to financing burdens, especially for elderly people and patients with rare diseases.

As mentioned in the section "Healthcare System Outcome" there are no significant changes planned to improve accessibility to healthcare for the poor and vulnerable people and there is no initiative in the change of the state budgetary assignment or to provide progressivity in taxation system.

\subsection{Responsiveness}

The fifth domain "responsiveness" that evaluates patients' satisfaction, choice availability, respect and dignity for patients - cannot be evaluated in Latvia because there is no data 
publicly available. In some hospitals there is a quality management system implemented, but there is no data available on the whole healthcare system evaluation.

\section{Conclusions}

During the research evaluation of five main segments of healthcare system has been made. In accordance with the research results the main problems of healthcare system performance are in the domain of healthcare system outcome. The main problems that have been recognized are:

1. Based on a high level of people at poverty and social exclusion risk and high rate of unmet needs with the leading cause "cannot afford it" it can be concluded that work on social determinants had not been done and the main values - universal coverage, equity and accessibility have not been reached.

2. The state has not increased funding to the healthcare, healthcare and health promotion have not become the priority of the government, despite all the recommendations from local and foreign experts. The concept "health in all policies" has not been implemented.

3. Primary healthcare in accordance with the data of emergency department usage and publicly expressed problem about quota on healthcare service availability indicates that healthcare services are not provided effectively and it leads to poorer society health, inability to get medical examination and treatment timely.

4. Although the legislature to provide environment that fosters healthy behaviour is accepted, the social campaigns haven't been effective and there are still actions that have to be taken to improve public health, decrease morbidity and mortality of diseases related to unhealthy life-style: healthier food, enhance physical activities, reduce usage of tobacco and alcohol.

5. Improvement of healthcare governance is the main direction where the changes have to be made - to work on the guidelines and policies that provide more appropriate use of resources according to the society needs, improve efficiency of resource usage, providing technical assessment and rationalizing the network of service providers.

6. According to the evaluation and analysis of healthcare system performance and health policy in Latvia, priorities declared by the Ministry of Health are not coherent to the society needs, based on statistical indicators. Although neoplasm is the second leading death cause in Latvia, activities provided by the Ministry of Health in oncology field couldn't provide benefits for the whole society. The main problems according to the results of the research are primary care availability (especially for the poor and vulnerable people), improvements in primary health availability could lead to efficiency and better system outcome.

7. The second direction that Ministry of Health has to work on is to provide more effective funding usage - providing technology assessment and appropriate network of service providers.

8. Overall conclusion is that changes in the healthcare system in Latvia are made on "ad-hoc" basis due to priorities seen by the current minister and without a strategic long-term plan, there are no defined tasks and metrics that have to be achieved to provide available and sustainable healthcare system. The reforms are made without impact assessment on the society and public health, they are not in accordance with the main values expressed in WHO policy "Health 2020" universal coverage, equity in access, effective and efficient governance. 


\section{References}

1. Ministru Kabinets. Rīkojums Nr.547 "Par veselības aprūpes reformas vidusposma un tālākās attīstības ndorošināšanas pamatnostādnēm (30.09.2002)

2. Ministru Kabinets. Noteikumi Nr.1026 "Veselības aprūpes organizēšanas un finansēšanas kārtība" (21.12.2004)

3. Central Statistical Bureau of Latvia. VAG01. Basic indicators of health care services at the end of the year, Period: 1997-2015

4. Central Statistical Bureau of Latvia. VAG15. Physicians by speciality at the end of the year. Physicians total, Period: 1997-2016

5. Central Statistical Bureau of Latvia. VAG16. Medical personnel with secondary medical education at the end of the year. Nurses, Period: 1997-2015

6. European Commission. Commission staff working document. Country Report Latvia 2016. Brussels, 26.2.2016

7. Central Statistical Bureau of Latvia. VPG07. Need to undergo medical examination or treatment at health care provider (except dentist) and reasons for unmet need for medical care for persona aged 16 or over (\%), Period: 2005-2014

8. Saeima of the Republic of Latvia. Sustainable development Strategy of Latvia until 2030, June, 2010

9. World Health Organization Regional office for Europe. Health 2020. A European policy framework and strategy for the 21 st century (2013)

10. The Cabinet of the Ministers of Latvia. Public Health Guidelines 2014-2020, 30.09.2014

11. European Observatory on Health Systems and Policies, edited by I. Papanicolas and P.C. Smith. Health System Performance Comparison. An Agenda for policy, information and research, 1-29 (2013)

12. Centre for Disease Prevention and Control of Latvia. Latvijas Skolēnu veselības paradumu pētījums 2013./2014.mācību gada aptaujas rezultāti un tendences. Rīga, 2015

13. Central Statistical Bureau of Latvia. IMG07. Average life expectancy at birth (years) Period: 2008-2015

14. Central Statistical Bureau of Latvia. IMG051. Perinatal, neonatal and infant death rates. Period: 2008-2015

15. Centre for Disease Prevention and Control of Latvia. Statistikas dati par 2015.gadu. Mirstība. Iedzīvotāju mirstība uz 100000 iedzīvotājiem.Dati atjaunoti 31.03.2016

16. Centre for Disease Prevention and Control of Latvia. Pārskats par neatliekamās medicīnas palīdzības darbību

17. A. Slokenberga. Universitātes slimnīcai nav jāstrādā lieljaudas poliklīnikas režīmā. RAKUS/ Aktualitātes, 29.09.2016

18. Organisation for Economic Co-operation and Development. OECD. Stat Government schemes and compulsory contributory health care financing schemes. Data extracted on 22.01.2017

19. Eurostat. People at risk of poverty or social exclusion by age and sex. Data last updated 15.12.2016

20. The World Bank. World Development Indicators. Out-of-Pocket health expenditures (\% of total expenditure on health) Latvia. 2008-2014 